\title{
Comparative evaluation of antimicrobial efficacy of triple antibiotic paste, calcium hydroxide, and a proton pump inhibitor against resistant root canal pathogens
}

\author{
Shibha Mehta ${ }^{1}$, Promila Verma $^{1}$, Aseem Prakash Tikku ${ }^{1}$, Anil Chandra ${ }^{1}$, Rhythm Bains ${ }^{1}$, \\ Gopa Banerjee ${ }^{2}$
}

Correspondence: Dr. Rhythm Bains

Email: docrhythm77@gmail.com

\begin{abstract}
'Department of Conservative Dentistry and Endodontics, Faculty of Dental Sciences, King George's Medical University, Lucknow, Uttar Pradesh, India, 2Department of Microbiology, King George's Medical University, Lucknow, Uttar Pradesh, India
\end{abstract}

\section{ABSTRACT}

Objective: The objective of this study is to compare the antimicrobial efficacy of triple antibiotic paste (TAP) and a proton pump inhibitor (PPI) (omeprazole) in combination with calcium hydroxide (CH) against Enterococcus faecalis and Candida albicans. Materials and Methods: E. faecalis and C. albicans were subcultured and inoculated at $37^{\circ}$ overnight and were treated with different dilutions of TAP, $25 \mu \mathrm{g} / \mathrm{ml}$ (Group 1), CH (Group 2, control), CH $16 \mathrm{mg} / \mathrm{ml}+$ omeprazole $2 \mathrm{mg} / \mathrm{ml}$ (Group 3a) $(\mathrm{CH} 16 \mathrm{mg} / \mathrm{ml}+$ omeprazole $4 \mathrm{mg}$ )/ml (Group 3b) for 24, 48, and $72 \mathrm{~h}$ in sterile uncoated 96 -well microtiter plates. Minimum concentration at which the medicaments produced least optical density was determined using ELISA reader (ELx 808 BioTek Inc., USA) device set at optical density of $630 \mathrm{~nm}$. Results were analyzed statistically by one-way analysis of variance followed by Tukey's multiple comparison tests. The significance level was set at 0.05 . Results: Mean concentration (irrespective of time) for TAP at which mean minimum optical density was recorded at $1.25 \mu \mathrm{g} / \mathrm{ml}$ (1:20 dilution) and $25 \mu \mathrm{g} / \mathrm{ml}$ (0 dilution) against E. faecalis and C. albicans, respectively. Least optical density for CH plus PPI group was obtained $1.6 \mu \mathrm{g} / \mathrm{ml}$ (1:10 dilution) and $16 \mu \mathrm{g} / \mathrm{ml}$ ( 0 dilution) for $E$. faecalis and $C$. albicans, respectively. However, $\mathrm{CH}$ alone showed a weaker antimicrobial action against either of the strains even at full concentration. Conclusions: PPI enhanced the antibacterial efficacy of $\mathrm{CH}$ against $E$. faecalis and C. albicans. However, TAP showed the best antibacterial property followed by $\mathrm{CH}$ plus PPIs against both the selected strains.

Key words: Candida albicans, Enterococcus faecalis, intracanal medicament

\section{INTRODUCTION}

Bacterial microflora of primary endodontic infections differs vastly from secondary or persistent periradicular lesions. The most frequent survivors present in a very high proportion of root canal failure cases are Enterococcus faecalis, Gram-positive,

\begin{tabular}{|l|l|}
\hline \multicolumn{3}{|c|}{ Access this article online } \\
\hline Quick Response Code: \\
\hline
\end{tabular}

and facultative anaerobe with the prevalence of $24 \%-77 \%{ }^{[1,2]}$ It has an inherent ability to invade deep inside dentinal tubules, survive periods of starvation, and withstand extremes of $\mathrm{pH}$ of medicaments such

This is an open access article distributed under the terms of the Creative Commons Attribution-NonCommercial-ShareAlike 3.0 License, which allows others to remix, tweak, and build upon the work non-commercially, as long as the author is credited and the new creations are licensed under the identical terms.

For reprints contact: reprints@medknow.com

How to cite this article: Mehta S, Verma P, Tikku AP, Chandra A Bains R, Banerjee G. Comparative evaluation of antimicrobial efficacy of triple antibiotic paste, calcium hydroxide, and a proton pump inhibitor against resistant root canal pathogens. Eur J Dent 2017;11:53-7.

DOI: 10.4103/ejd.ejd_159_16 
as calcium hydroxide $(\mathrm{CH}) \cdot{ }^{[3,4]}$ Interestingly, this resistance to withstand the alkaline stress induced by $\mathrm{CH}$ is also shared with Candida albicans; another resistant pathogen in teeth with periradicular lesions with the prevalence of $6 \%-18 \%{ }^{[5,6]}$

Both bacteria and fungi express a proton pump in their plasma membrane for energy metabolism and maintenance of constant cytoplasmic $\mathrm{pH}^{[7,8]}$ that enables E. faecalis and C. albicans to maintain the homeostasis of the cytoplasm and survive the high alkaline $\mathrm{pH}$ of $\mathrm{CH} .{ }^{[9,10]}$ Moreover, dentin neutralizes the high $\mathrm{pH}$ of $\mathrm{CH}$ by exerting a buffering effect. ${ }^{[1]}$

Triple antibiotic paste (TAP) comprising ciprofloxacin, metronidazole, and minocycline has the potential to eradicate microbes residing deep inside the dentinal tubules. ${ }^{[12]}$ However, its use TAP can cause discoloration of teeth due to minocycline present in it. ${ }^{[13]}$ Another primary concern is resistance of bacteria to antibiotics and cytotoxic effects of TAP to stem cells and periradicular tissues when used at higher

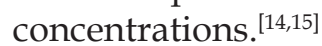

Recently, proton pump inhibitors (PPIs) were proposed as an adjuvant to intracanal medicaments. These cause an irreversible inhibition of the $\mathrm{H}+/ \mathrm{K}+$ ATPase in the parietal cells of the stomach leading to reduced gastric acid secretion, and thus are a drug of choice for gastric/duodenal ulcers and gastroesophageal reflux diseases. They increase the efficacy of antibiotics by decreasing the intragastric acidity. ${ }^{[16]}$ PPIs have also been found to exert antioxidant properties by directly affecting the neutrophils, monocytes, endothelial, and epithelial cells. ${ }^{[17]}$

Although the role of proton pump in the survival of resistant endodontic pathogens is known, a limited research is carried out to evaluate the antibacterial efficacy of PPIs. The aim of the present study was thus to evaluate the effect of the addition of omeprazole on antimicrobial efficacy of $\mathrm{CH}$ against E. faecalis and C. albicans in comparison to that of TAP.

\section{MATERIALS AND METHODS}

\section{Bacterial strains and media}

E. faecalis, American type culture collection (ATCC 29212) and C. albicans (ATCC 90028) were subcultured on sheep blood agar and Sabouraud dextrose agar plates, respectively, and incubated aerobically at $37^{\circ}$ overnight.

\section{Preparation of medicament working strength solutions}

Ciprofloxacin, metronidazole, and minocycline for $\mathrm{TAP}, \mathrm{CH}$, and omeprazole were obtained in powder form (Sigma-Aldrich; Mumbai, Maharashtra, India). $\mathrm{CH}$ was dissolved in distilled water at room temperature to prepare a saturated solution, centrifuged at $3000 \mathrm{rpm}$ for $15 \mathrm{~min}$, and the aqueous supernatant layer was filter sterilized using a sterile 25-mm syringe filter. Working strength solution of each medicament group was prepared by diluting them with distilled water and final concentration tested for antibacterial efficacy was as follows:

- Group 1: (TAP)-25 $\mu \mathrm{g} / \mathrm{ml}$

- Group 2: $(\mathrm{CH})-16 \mathrm{mg} / \mathrm{ml}$

- Group 3a: (CH $16 \mathrm{mg}+$ omeprazole $2 \mathrm{mg}) / \mathrm{ml}$

- Group 3b: (CH16 mg/ml + omeprazole $4 \mathrm{mg}) / \mathrm{ml}$.

\section{Preparation of 0.5 McFarland}

The density of each strain was adjusted equal to that of 0.5 McFarland standard $(1.5 \times 108) \mathrm{CFU} / \mathrm{ml}$ after inoculating in BHI-YE broth supplemented with $5 \mathrm{~g}$ yeast extract/L and $5 \% \mathrm{v} / \mathrm{v}$ Vitamin $\mathrm{K}+$ hemin. McFarland was used as a reference to adjust the turbidity of microbial suspension.

Two-fold microdilution assay was performed on 96-well sterile uncoated microtiter plates (tarsons) as per The Clinical and Laboratory Standards Institute guidelines. ${ }^{[18]}$ Strains were treated with 1:10, 1:20, 1:40, 1:80, 1:160, 1:320,1:640, 1:1280, and 1:2560 dilutions of each medicament group for 24,48 , and $72 \mathrm{~h}$. Bacterial growth appeared as turbidity or as a deposit of cells at the bottom of a well. The turbidities of the bacterial cultures of each well were measured using a microplate reader device (ELx 808 Biotek Inc., USA) set at $630 \mathrm{~nm}$. All the readings were taken in triplicate, and the minimum mean concentration of the drug which produced least optical density for that group was recorded. Eleventh well was negative control, in which only broth was added without bacterial inoculums and $12^{\text {th }}$ well as a positive control, free of antibiotics.

\section{Statistical analysis}

One-way analysis of variance (ANOVA) followed by Tukey's multiple comparisons tests was used to compare the optical density among the groups at different concentrations at 24,48 , and $72 \mathrm{~h}$. The effect of time on the optical density of various groups was tested using two-way ANOVA and pairwise comparisons. The significance level was set at 0.05 . All the analysis was carried out using SPSS version 16 (SPSS Inc., Chicago, IL, USA). 


\section{RESULTS}

Mean concentration (in $\mu \mathrm{g} / \mathrm{ml}$ ) and dilution at which minimum optical density was recorded for each drug tested at various time intervals is depicted in Table 1.

ANOVA revealed a significant difference in the E. faecalis and C. albicans optical density at 24,48 , and $72 \mathrm{~h}$ among all the groups in different concentrations. When evaluated irrespective of time, mean minimum optical density for TAP was obtained at $1.25 \mu \mathrm{g} / \mathrm{ml}$ (1:20 dilution) and $25 \mu \mathrm{g} / \mathrm{ml}$ (0 dilution) against E. faecalis and C. albicans. Least optical density for $\mathrm{CH}$ plus PPI group was achieved $1.6 \mu \mathrm{g} / \mathrm{ml}$ (1:10 dilution) and $16 \mu \mathrm{g} / \mathrm{ml}$ (0 dilution) for E. faecalis and C. albicans [Table 2 and Figures 1,2]. The pairwise comparison tests revealed that optical density for both strains was

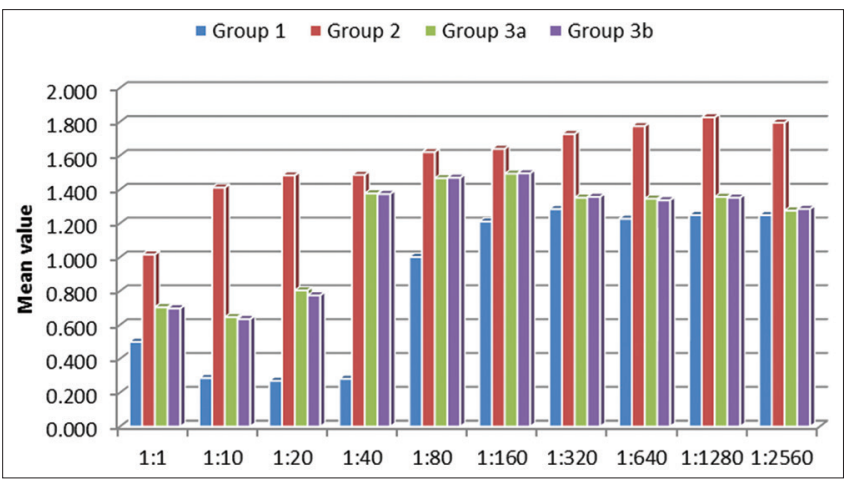

Figure 1: Mean \pm standard deviation of effect of dilutions on Enterococcus faecalis optical density among the groups in different concentrations irrespective of time significantly $(P=0.0001)$ lower in Group 1 (TAP) than Group $2(\mathrm{CH})$, Group 3a ( $\mathrm{CH}+$ omeprazole $2 \mathrm{mg})$, and Group 3b $(\mathrm{CH}+$ omeprazole $4 \mathrm{mg})$ at all the concentrations but significantly higher $(P=0.0001)$ in Group $2(\mathrm{CH})$ compared to Group $3 a(\mathrm{CH}+$ omeprazole $2 \mathrm{mg}$ and Group $3 \mathrm{~b}(\mathrm{CH}+$ omeprazole $4 \mathrm{mg})$ at all the concentrations. There was no significant $(P>0.05)$ difference in the optical density for both strains between Group 3a $(\mathrm{CH}+$ omeprazole $2 \mathrm{mg})$ and Group 3b $(\mathrm{CH}+$ omeprazole $4 \mathrm{mg})$ at all the concentrations. The two-way ANOVA revealed that there was a significant effect of time $(P<0.01)$ at all the concentrations in the optical density for both the strains. The interaction of Group X Time was also found to be statistically significant $(P<0.05)$ at all the concentrations in the optical density.

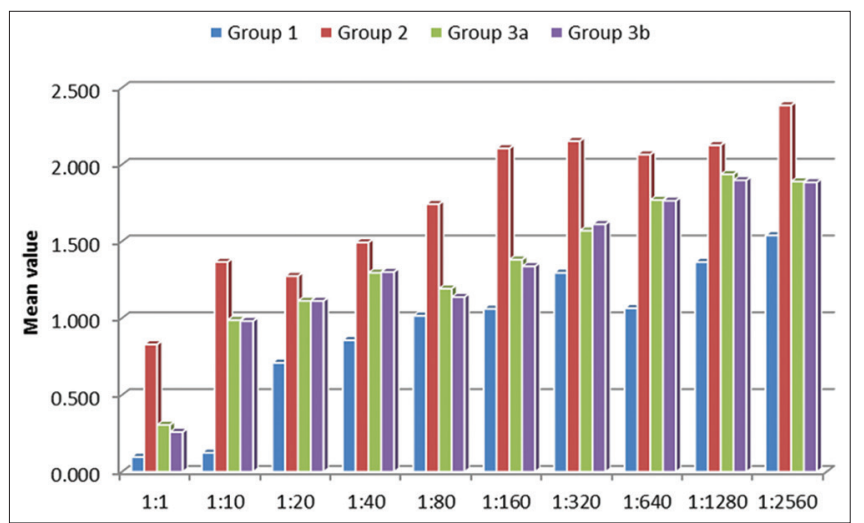

Figure 2: Mean \pm standard deviation of effect of dilutions on Candida optical density among the groups in different concentrations irrespective of time

\begin{tabular}{|c|c|c|c|c|c|c|}
\hline & \multicolumn{3}{|c|}{ E. faecalis } & \multicolumn{3}{|c|}{ C. albicans } \\
\hline & $24 \mathrm{~h}$ & $48 \mathrm{~h}$ & $72 \mathrm{~h}$ & $24 \mathrm{~h}$ & $48 \mathrm{~h}$ & $72 \mathrm{~h}$ \\
\hline TAP & $\begin{array}{c}1.25 \mu \mathrm{g} / \mathrm{ml} \\
\text { (1:20 dilution) }\end{array}$ & $\begin{array}{c}1.25 \mu \mathrm{g} / \mathrm{ml} \\
\text { (1:20 dilution) }\end{array}$ & $\begin{array}{c}1.25 \mu \mathrm{g} / \mathrm{ml} \\
\text { (1:20 dilution) }\end{array}$ & $\begin{array}{l}25 \mu \mathrm{g} / \mathrm{ml} \\
\text { (0 dilution) }\end{array}$ & $\begin{array}{c}2.5 \mu \mathrm{g} / \mathrm{ml} \\
\text { (1:10 dilution) }\end{array}$ & $\begin{array}{c}1.25 \mu \mathrm{g} / \mathrm{ml} \\
(1: 20 \text { dilution })\end{array}$ \\
\hline $\mathrm{CH}$ & $\begin{array}{c}1.6 \mu \mathrm{g} / \mathrm{ml} \\
\text { (1:10 dilution) }\end{array}$ & $\begin{array}{c}1.6 \mu \mathrm{g} / \mathrm{ml} \\
\text { (1:10 dilution) }\end{array}$ & $\begin{array}{c}16 \mu \mathrm{g} / \mathrm{ml} \\
\text { (0 dilution) }\end{array}$ & $\begin{array}{c}16 \mu \mathrm{\mu g} / \mathrm{ml} \\
\text { (0 dilution) }\end{array}$ & $\begin{array}{c}16 \mu \mathrm{gg} / \mathrm{ml} \\
(0 \text { dilution })\end{array}$ & $\begin{array}{c}0.8 \mu \mathrm{g} / \mathrm{ml} \\
\text { (1:20 dilution) }\end{array}$ \\
\hline $\mathrm{CH}+$ omeprazole $2 \mathrm{mg}$ & $\begin{array}{c}0.8 \mu \mathrm{g} / \mathrm{ml} \\
\text { (1:20 dilution) }\end{array}$ & $\begin{array}{c}1.6 \mu \mathrm{g} / \mathrm{ml} \\
\text { (1:10 dilution) }\end{array}$ & $\begin{array}{c}1.6 \mu \mathrm{g} / \mathrm{ml} \\
\text { (1:10 dilution) }\end{array}$ & $\begin{array}{c}16 \mu \mathrm{g} / \mathrm{ml} \\
\text { (0 dilution) }\end{array}$ & $\begin{array}{c}16 \mu \mathrm{g} / \mathrm{ml} \\
\text { (0 dilution) }\end{array}$ & $\begin{array}{c}16 \mu \mathrm{g} / \mathrm{ml} \\
\text { (0 dilution) }\end{array}$ \\
\hline $\mathrm{CH}+$ omeprazole $4 \mathrm{mg}$ & $\begin{array}{c}1.6 \mu \mathrm{g} / \mathrm{ml} \\
\text { (1:10 dilution) }\end{array}$ & $\begin{array}{c}1.6 \mu \mathrm{g} / \mathrm{ml} \\
\text { (1:10 dilution) }\end{array}$ & $\begin{array}{c}1.6 \mu \mathrm{g} / \mathrm{ml} \\
\text { (1:10 dilution) }\end{array}$ & $\begin{array}{l}16 \mu \mathrm{\mu g} / \mathrm{ml} \\
\text { (0 dilution) }\end{array}$ & $\begin{array}{l}16 \mu \mathrm{g} / \mathrm{ml} \\
\text { (0 dilution) }\end{array}$ & $\begin{array}{l}16 \mu \mathrm{g} / \mathrm{ml} \\
\text { (0 dilution) }\end{array}$ \\
\hline
\end{tabular}

faecalis: Enterococcus faecalis, C. albicans: Candida albicans, TAP: Triple antibiotic paste, $\mathrm{CH}$ : Calcium hydroxide

\begin{tabular}{|c|c|c|c|c|}
\hline \multirow[t]{2}{*}{ Microbial strains } & \multicolumn{4}{|c|}{ Drug tested } \\
\hline & TAP & $\mathrm{CH}$ & $\mathrm{CH}+$ omeprazole $2 \mathrm{mg}$ & $\mathrm{CH}+$ omeprazole $4 \mathrm{mg}$ \\
\hline E. faecalis & $1.25 \mu \mathrm{g} / \mathrm{ml}$ (1:20 dilution) & $16 \mu \mathrm{g} / \mathrm{ml}$ (0 dilution) & $1.6 \mu \mathrm{g} / \mathrm{ml}(1: 10$ dilution $)$ & $1.6 \mu \mathrm{g} / \mathrm{ml}$ (1:10 dilution) \\
\hline C. albicans & 25 g/ml (0 dilution) & $16 \mu \mathrm{g} / \mathrm{ml}$ (0 dilution) & 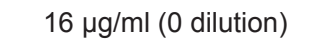 & 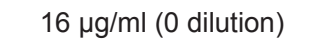 \\
\hline
\end{tabular}




\section{DISCUSSION}

Microtiter plate method was adopted considering the usual contamination and difficulty in obtaining bacterial samples from the inherent complexities of root canal system. In addition, it is a quantitative and reproducible method that simulates the contact of the test microorganism with endodontic medicaments inside the root canal. Furthermore, the accuracy and feasibility of this approach substantially reduce the waiting time involved in standard laboratory antibacterial sensitivity assays.

The results suggest that $\mathrm{CH}$ alone was not as effective against the tested strains compared to other groups. Visible bacterial growth was observed in all the wells at 24,48 , and $72 \mathrm{~h}$ and minimum optical density was obtained only at full concentration. $\mathrm{CH}$ owes its antimicrobial property mainly to its high $\mathrm{pH}(>11)$ but it is practically difficult to achieve this high $\mathrm{pH}$ throughout the length of the canal because of the buffering capacity of dentin, especially in the dentinal tubules. ${ }^{[19]}$ Furthermore, the presence of proton pump in its cell membrane $E$. faecalis sustains the alkaline effect of $\mathrm{CH}$ dressing by allowing pumping of the protons into the cytoplasm and hence lowering the $\mathrm{pH} .{ }^{[10,20]}$ Tang et al. listed the ability of microorganisms to survive in dentinal tubule ramifications, fall in $\mathrm{pH}$, and microleakage of the temporary filling as some of the limitations of $\mathrm{CH}$ as an intracanal medicament. ${ }^{[21]}$

TAP delivered statistically significant inhibition of E. faecalis and C. albicans at 24,48 , and $72 \mathrm{~h}$. TAP achieved least optical density at 1:20 dilution $(1.25 \mu \mathrm{g} / \mathrm{ml})$ against E. faecalis at all time intervals; however, for Candida, maximum inhibition of growth was seen only at highest concentration, i.e., $25 \mu \mathrm{g} / \mathrm{ml}$ at $24 \mathrm{~h}, 1: 10$ dilution $(2.5 \mu \mathrm{g} / \mathrm{ml})$ at $48 \mathrm{~h}$, and 1:20 dilution $(1.25 \mu \mathrm{g} / \mathrm{ml})$ at $72 \mathrm{~h}$. Hoshino et al. concluded that a combination of ciprofloxacin, metronidazole, and minocycline at a concentration of $25 \mu \mathrm{g} / \mathrm{ml}$ each per milliliter of paste was able to sterilize infected root dentin in vitro. ${ }^{[12]}$ Sato et al. reported $50 \mu \mathrm{g} / \mathrm{ml}$ of each antibiotic per milliliter was sufficient to sterilize infected root dentin in situ. ${ }^{[22]}$ In this study, TAP was found to be effective even at high dilutions, indicating that low concentrations of antibiotics might be sufficient to obtain the required antibacterial effect.

Th addition of omeprazole to $\mathrm{CH}$ showed synergism and achieved least optical density at 1:10 dilution $(1.6 \mu \mathrm{g} / \mathrm{ml})$ against E. faecalis; however, for Candida, it showed antifungal property only at maximum concentration and variation in the concentration; whether $2 \mathrm{mg}$ or $4 \mathrm{mg}$ of omeprazole did not affect the result. This synergism may be due to the irreversible inhibition of proton pump in the cell membrane of the E. faecalis and C. albicans. ${ }^{[23]}$

Evans et al. ${ }^{[10]}$ demonstrated that survival of E. faecalis in $\mathrm{CH}$ is unrelated to stress-induced protein synthesis, but more the result of a proton pump that pumps protons into the cell to acidify the cytoplasm. The present data are in accordance with a previous in an in vivo study which has revealed that, the combination of a PPI, omeprazole with $\mathrm{CH}$ when used as an intracanal medicament exhibited increased antimicrobial efficacy against $E$. faecalis and superior radiographic healing of periapical lesions with increase in reparative bone areas in male Wistar rats compared CH. ${ }^{[24]}$ Apart from antibacterial properties, PPIs exert anti-inflammatory and pro-reparative effects which enhance the healing of the periapical area. ${ }^{[20]}$

Although the results of this study using PPIs as an adjuvant to intracanal medicament were promising, an in vitro agar diffusion assay demonstrated that the addition of PPI (Pantoprazole) to $\mathrm{CH}$ did not enhance the antimicrobial efficacy of $\mathrm{CH}$ when compared to chlorhexidine. ${ }^{[25]}$ The variation in results may be due to the difference in the tested drugs and methodology used. The present experiment suggested that the PPIs were not very effective against $C$. albicans at the concentrations employed in the study. Omeprazole exhibits an "eagle" or "paradoxical effect," i.e., its antifungal action is seen at a particular concentration but disappears at a higher or lower range. ${ }^{[26]}$ One of the limitations of the present study was not using a biofilm model for testing $E$. faecalis which would have more closely simulated the clinical situation as it occurs mostly as extra- or intra-radicular plaque.

\section{CONCLUSIONS}

Although in the present study, the best antibacterial property among the study groups was exhibited by TAP, followed by $\mathrm{CH}$ plus PPIs, the results also demonstrate the synergistic antimicrobial efficacy of $\mathrm{CH}$ and PPIs against E. faecalis and C. albicans. In addition, the results suggest that the TAP can be used at a lower concentration than it is being used to avoid the deleterious effects associated with higher concentrations.

However, in real-life situations, dentin exerts a buffering effect on endodontic disinfectants. Hence, 
the antibacterial activity of PPIs along with $\mathrm{CH}$ as an intracanal medicament needs to be tested in the clinical scenario to establish it as a potential chemical adjunct to endodontic therapy.

\section{Financial support and sponsorship Nil.}

\section{Conflicts of interest}

There are no conflicts of interest.

\section{REFERENCES}

1. Molander A, Reit C, Dahlén G, Kvist T. Microbiological status of root-filled teeth with apical periodontitis. Int Endod J 1998;31:1-7.

2. Chávez De Paz LE, Dahlén G, Molander A, Möller A, Bergenholtz G. Bacteria recovered from teeth with apical periodontitis after antimicrobial endodontic treatment. Int Endod J 2003;36:500-8.

3. Mistry KS, Sanghvi Z, Parmar G, Shah S. The antimicrobial activity of Azadirachta indica, Mimusops elengi, Tinospora cardifolia, Ocimum sanctum and $2 \%$ chlorhexidine gluconate on common endodontic pathogens: An in vitro study. Eur J Dent 2014;8:172-7.

4. Dammaschke T, Jung N, Harks I, Schafer E. The effect of different root canal medicaments on the elimination of Enterococcus faecalis ex vivo. Eur J Dent 2013;7:442-8.

5. Waltimo TM, Sirén EK, Orstavik D, Haapasalo MP. Susceptibility of oral Candida species to calcium hydroxide in vitro. Int Endod J 1999;32:94-8

6. Ning Y, Hu X, Ling J, Du Y, Liu J, Liu H, et al. Candida albicans survival and biofilm formation under starvation conditions. Int Endod J 2013;46:62-70.

7. Booth IR. Regulation of cytoplasmic $\mathrm{pH}$ in bacteria. Microbiol Rev 1985;49:359-78

8. Kakinuma Y. Lowering of cytoplasmic $\mathrm{pH}$ is essential for growth of Streptococcus faecalis at high $\mathrm{pH}$. J Bacteriol 1987;169:4403-5.

9. Siqueira JF Jr., Lopes HP. Mechanisms of antimicrobial activity of calcium hydroxide: A critical review. Int Endod J 1999;32:361-9.

10. Evans M, Davies JK, Sundqvist G, Figdor D. Mechanisms involved in the resistance of Enterococcus faecalis to calcium hydroxide. Int Endod J 2002;35:221-8.

11. Haapasalo HK, Sirén EK, Waltimo TM, Ørstavik D, Haapasalo MP. Inactivation of local root canal medicaments by dentine: An in vitro study. Int Endod J 2000;33:126-31.

12. Hoshino E, Kurihara-Ando N, Sato I, Uematsu H, Sato M, Kota K, et al.
In-vitro antibacterial susceptibility of bacteria taken from infected root dentine to a mixture of ciprofloxacin, metronidazole and minocycline. Int Endod J 1996;29:125-30.

13. Abbott PV, Hume WR, Pearman JW. Antibiotics and endodontics. Aust Dent J 1990;35:50-60.

14. Ruparel NB, Teixeira FB, Ferraz CC, Diogenes A. Direct effect of intracanal medicaments on survival of stem cells of the apical papilla. J Endod 2012;38:1372-5.

15. Chuensombat S, Khemaleelakul S, Chattipakorn S, Srisuwan T. Cytotoxic effects and antibacterial efficacy of a 3-antibiotic combination: An in vitro study. J Endod 2013;39:813-9.

16. Olbe L, Carlsson E, Lindberg P. A proton-pump inhibitor expedition: The case histories of omeprazole and esomeprazole. Nat Rev Drug Discov 2003;2:132-9.

17. Loo VG, Fallone CA, De Souza E, Lavallée J, Barkun AN. In-vitro susceptibility of Helicobacter pylori to ampicillin, clarithromycin, metronidazole and omeprazole. J Antimicrob Chemother 1997;40:881-3.

18. CLSI. Performance Standards for Antimicrobial Susceptibility Testing; Twenty-fourth Informational Supplement. CLSI document M100-S24. Wayne PA: Clinical and Laboratory Standards Institute; 2014.

19. Estrela C, Silva JA, de Alencar AH, Leles CR, Decurcio DA. Efficacy of sodium hypochlorite and chlorhexidine against Enterococcus faecalis - A systematic review. J Appl Oral Sci 2008;16:364-8.

20. Kedika RR, Souza RF, Spechler SJ. Potential anti-inflammatory effects of proton pump inhibitors: A review and discussion of the clinical implications. Dig Dis Sci 2009;54:2312-7.

21. Tang G, Samaranayake LP, Yip HK. Molecular evaluation of residual endodontic microorganisms after instrumentation, irrigation and medication with either calcium hydroxide or Septomixine. Oral Dis 2004;10:389-97.

22. Sato I, Ando-Kurihara N, Kota K, Iwaku M, Hoshino E. Sterilization of infected root-canal dentine by topical application of a mixture of ciprofloxacin, metronidazole and minocycline in situ. Int Endod J 1996;29:118-24.

23. Kakinuma Y. Inorganic cation transport and energy transduction in Enterococcus hirae and other streptococci. Microbiol Mol Biol Rev 1998;62:1021-45.

24. Wagner C, Barth VC Jr., de Oliveira SD, Campos MM. Effectiveness of the proton pump inhibitor omeprazole associated with calcium hydroxide as intracanal medication: An in vivo study. J Endod 2011;37:1253-7.

25. Suresh M, Abraham TA, Padmavathy K, Mahalakshmi K, Venkatesh A, Vivekanandhan $\mathrm{P}$, et al. Pantoprazole- does it enhance the antibacterial efficacy of calcium hydroxide against Enterococcus faecalis. Int J Pharm Bio Sci 2015;6:734-9.

26. Küçükaslan F, Vural HC, Berber D, Severoğlu Z, Sümer S, Doykun M. Assessment of antifungal effect of omeprazole on Candida albicans. Int J Biotechnol Mol Biol Res 2013;4:45-51. 